\title{
Key considerations for a pre-emergency survival pack: a hypothetical case study
}

\author{
Alvin Khah*, Jason Lee \\ From 15th International Conference on Environmental Ergonomics (ICEE XV) \\ Portsmouth, UK. 28 June - 3 July 2015
}

\section{Introduction}

Populations affected by natural disasters usually rely heavily on search and rescue operations and relief supplies to sustain their road to recovery. It is observed that few survivors are recovered after 2 weeks ${ }^{1}$ of continuous search and rescue efforts and limited resources are distracted from aiding rescued survivors. Hence, individuals living in natural disaster prone areas or have received early warning for an impending disaster may consider owning/be provided with a pre-emergency nutritional pack for self-sufficiency. In addition, collapsed structures may entrap victims in confined spaces with limited oxygen supply and faces the danger of hypercapnia, so a hypothetical example of a 20 year old healthy male in 14 day entrapment was used to demonstrate the dietary, $\mathrm{CO}_{2}$ output and $\mathrm{CO}_{2}$ scrubbing requirements. A commercially available $20 \mathrm{~g}$ protein bar and lithium hydroxide $(\mathrm{LiOH})$ powder were used in the calculations to show how the content of such a preemergency pack can be tailored.

\section{Methods}

Calculations based on published sources of dietary requirements and $\mathrm{CO}_{2}$ emission of an adult.

\section{Discussion}

The dietary requirements in Table 1 provide the minimum nutrition for sustenance and minimise $\mathrm{CO}_{2}$ output from the entrapped 20 year old healthy male weighing $70 \mathrm{~kg}$ through 14 days in a $10 \mathrm{~m}^{3}$ space. The $\mathrm{CO}_{2}$ scrubbing capacity of this pre-emergency pack should also scrub any $\mathrm{CO}_{2}$ produced through respiration by the victim during this period of entrapment. Any dietary and/or $\mathrm{CO}_{2}$ scrubbing alternatives can be evaluated against these requirements and selected into the preemergency pack.

\section{Conclusion}

Prevention is better than cure in most, if not all, harmful situations. This novel pre-emergency survival pack is a convenient "first aid kit" for natural disasters. A carefully

Table 1 Emergency pack requirements for a 20 year old healthy male of 70 kg to survive an entrapment in $10 \mathrm{~m}^{3}$ space with healthy weight loss and maintaining $\mathrm{CO}_{2}$ concentration at initial level.

\begin{tabular}{lccc}
\hline & Daily & 14 days & Example of pre-Emergency Pack for 14 days \\
\hline Energy & $1190 \mathrm{kcal}$ & $16660 \mathrm{kcal}$ & 70 bars of “commercially available 20 g protein bar" \\
\hline Carbohydrate [2] & $130 \mathrm{~g}$ & $1820 \mathrm{~g}$ & \\
\hline Protein [2] & $56 \mathrm{~g}$ & $784 \mathrm{~g}$ & \\
\hline Fat & $49.5 \mathrm{~g}$ & $693 \mathrm{~g}$ & $\mathbf{3 5 \mathrm { L }}$ \\
\hline Sodium [2] & $500 \mathrm{mg}$ & $7000 \mathrm{mg}$ & $\mathbf{2 4} \mathbf{~ k g ~ o f ~ L i O H}$ \\
\hline Water [3] & $2.5 \mathrm{~L}$ & $35 \mathrm{~L}$ & \\
\hline $\mathbf{C O}_{\mathbf{2}}$ to be scrubbed & $0.637 \mathrm{~m}^{3}$ & $8.918 \mathrm{~m}^{3}$ & \\
\hline
\end{tabular}

\footnotetext{
* Correspondence: kkokleon@dso.org.sg

Human Performance Laboratory, Defence Medical and Environmental

Research Institute, DSO National Laboratories. Singapore
} 
designed pre-emergency pack can be easily adapted to the unique conditions of various disasters and enhance the survivability of a victim entrapped under debris at a site of natural disaster. Early distribution of pre-emergency survival packs will also ensure isolated rural dwellers to be selfsufficient, during the aftermath of a natural disaster, while awaiting arrival of relief supplies.

Published: 14 September 2015

\section{References}

1. Macintyre AG, Barbera JA, Smith ER: Surviving collapsed structure entrapment after earthquakes: a "time-to-rescue" analysis. Prehosp Disaster Med 2006, 21(1):4-17, discussion 18-9.

2. National Research Council: Dietary Reference Intakes: The Essential Guide to Nutrient Requirements. Washington, DC: The National Academies Press; 2006.

3. Reed B, Reed B: How much water is needed in emergencies? WEDC, Loughborough University, UK; 2011 [http://www.who.int/ water_sanitation_health/.../tn9_how_much_water_en.pdf].

doi:10.1186/2046-7648-4-S1-A63

Cite this article as: Khah and Lee: Key considerations for a preemergency survival pack: a hypothetical case study. Extreme Physiology \& Medicine 2015 4(Suppl 1):A63.

Submit your next manuscript to BioMed Central and take full advantage of:

- Convenient online submission

- Thorough peer review

- No space constraints or color figure charges

- Immediate publication on acceptance

- Inclusion in PubMed, CAS, Scopus and Google Scholar

- Research which is freely available for redistribution

Submit your manuscript at www.biomedcentral.com/submit 